\title{
Spermatogenic Stem Cell System in the Mouse Testis
}

\author{
S. YosHIDA \\ Division of Germ Cell Biology, National Institute for Basic Biology, \\ Higashiyama, Myodaiji, Okazaki 444-8787, Okazaki, Japan
}

\begin{abstract}
Mouse spermatogenesis represents a highly potent and robust stem cell system. Decades of research have made it one of the most intensively studied mammalian tissue stem cell systems. These studies include detailed morphological examinations, posttransplantation colony formation, and in vitro culture of the stem cells; however, the nature of the stem cells as well as their niche are mostly to be elucidated in the context of homeostatic spermatogenesis. Our group has been challenging this issue by means of transgenic and live-imaging approaches that enable the investigation of live behaviors of "undifferentiated spermatogonia," the candidate stem cell population. A pulse-label experiment has suggested a hierarchical composition of the stem cell functional compartments, unlike the general idea. In addition, live imaging revealed the preferential localization of undifferentiated spermatogonia in the area adjacent to the blood vessel, leading to the proposal of a vasculature-associated niche. These results have suggested the idea of "flexibility" in the mouse spermatogenic stem cell system, which makes a good contrast to the "strict" stem-cell-niche system observed, for example, in the Drosophila germ line. This flexible nature seems to be advantageous for mammalians.
\end{abstract}

\section{AN ANATOMICAL OVERVIEW OF MAMMALIAN SPERMATOGENESIS}

In mammals, the male gonad (i.e., the testis) carries a highly efficient stem cell system that continuously produces numerous differentiating cells (i.e., sperm) during the reproduction period (Russell et al. 1990; Meistrich and van Beek 1993; de Rooij and Russell 2000). Figure 1 represents the anatomical basis of mouse spermatogenesis: Spermatogenesis proceeds inside the seminiferous tubule, a convoluted tubular structure with a diameter of about 200 $\mu \mathrm{m}$ that connects to the common outlet of the mature sperm (rete testes) with both ends to form loops. Each mouse testis contains about 20 tubules that are highly convoluted and tightly packed inside the testicular capsule (tunica albuginea). Their total length is up to $2 \mathrm{~m}$, and spermtaogenesis occurs evenly throughout the inner surface of the tubules, the seminiferous epithelium. Therefore, in the mouse testis, an overall "polarity" that covers the entire organ cannot be recognized, as is clear in the gonads of several other "model organisms" such as Drosophila or Caenorhabditis elegans (Fig. 1A,B) (Decotto and Spradling 2005).
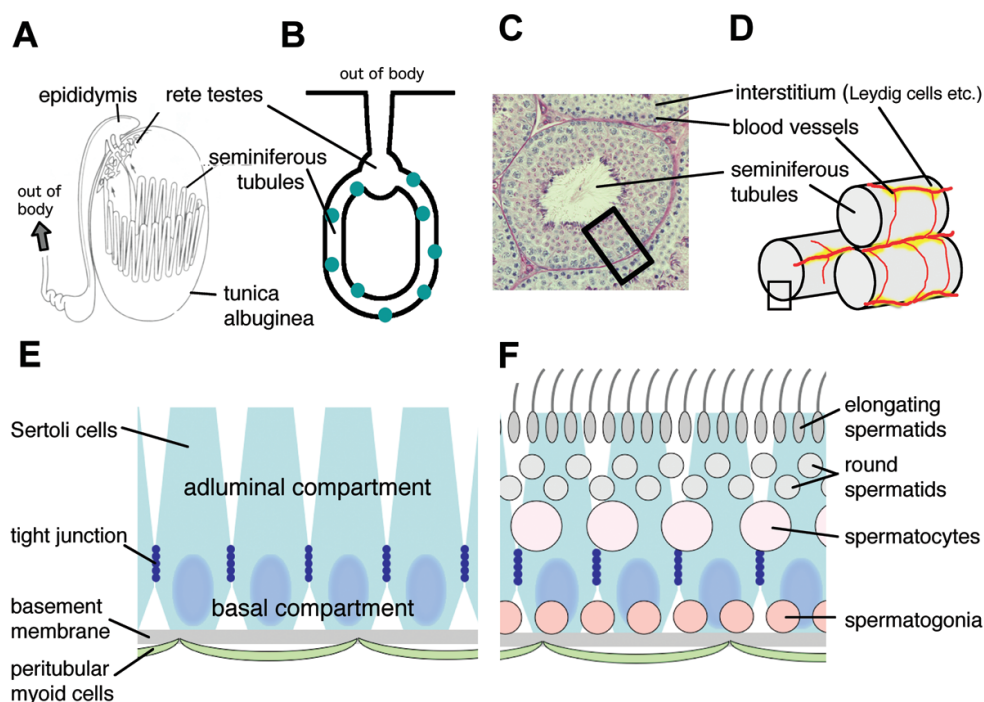

Figure 1. Anatomy of the mouse testis and seminiferous tubules. (A) Schematic overview of the mouse testis. Seminiferous tubules, the spermatogenic center of the testis, are highly convoluted and tightly packed in the tunica albuginea. A single tubule out of approximately 20 is shown. Individual tubules form loops with both ends open to the rete testis. $(B)$ Diagram of mouse seminiferous tubule topology. As shown by green dots, stem cells are scattered throughout the tubule loops, which do not show apparent overall polarity. $(C, D)$ Seminiferous tubules and the surrounding network of vasculature and interstitium. The blood vessels ( $r e d)$ never penetrate the seminiferous tubule, but instead they run through the interstitial space and form a network among the seminiferous tubules. Vessels are surrounded by Leydig and other types of interstitial cells (yellow). $(E, F)$ Scheme of the seminiferous epithelium and spermatogenesis, corresponding to the area shown by rectangles in $C$ and $D$. (E) Anatomical framework composed of somatic components; $(F)$ spermatogenic cells. See text for details. (Modified from Yoshida 2008 [@ Kyoritsu Shuppan].) 
Seminiferous tubules show a simple structural framework composed of Sertoli and peritubular myoid cells, the two somatic cell types that cover the inside and outside of the basement membrane, respectively (Fig. 1E). Sertoli cells show clear polarity and form a typical epithelium with tight junctions between them. The tight junction is the anatomical basis of the blood testis barrier and separates the tubules into basal and adluminal compartments. The basal compartment (i.e., between the junction and basement membrane) is occupied with spermatogonia (i.e., spermatogenic cells in mitotic stages) that contain stem cells and their differentiating progeny. Then, germ cells translocate to the adluminal compartment when entering meiosis, somehow through the tight junction. Subsequently, postmeiotic round and elongating spermatids are pushed up toward the lumen, which results in the beautifully arranged organization of the seminiferous epithelium (Fig. 1F) (Russell et al. 1990). The matured sperm are released into the lumen and ejaculated outside the body via the rete testes, epididymis, and vas deferens. The seminiferous tubules represent a common structure throughout the longitudinal and perpendicular; no specialized substructures or subsets of somatic cells that suggest a stem cell niche have been described. Blood vessels nourish the tubules but never penetrate them and run in the triangular intertubular interstitial space to form a network (Fig. 1C,D). Leydig cells (the main producer of testicular testosterone), lympathetic epithelium, and macrophages surround the vessels to form interstitium.

Mammalian spermatogenesis therefore progresses in an apparently different anatomical context from that elu- cidated in other organisms. To my understanding, this has made the mammalian spermatogenic stem cell system a big challenge: Which germ cell population acts as stem cells? How do they behave in the testis to achieve stem cell functions?

In this chapter, I overview the research of the mammalian spermatogenic stem cell system (mainly in the mouse system) from a historical point of view and summarize the essential achievements as well as their potential drawbacks that allow us to recognize the remaining essential questions. I then discuss our recent work with this important and attractive system. I hope that this chapter provides a direction for a fuller understanding of mammalian spermatogenesis.

\section{UNDIFFERENTIATED SPERMATOGONIA AND THE "As MODEL"}

The detailed morphological observations of testis sections and whole-mount seminiferous tubule specimens in the 1950s through the 1970s established the backbone of spermatogenesis research (Russell et al. 1990; Meistrich and van Beek 1993; de Rooij and Russell 2000). There is no doubt that spermatogenic stem cells consist of only a tiny fraction of spermatogonia; however, strictly speaking, it is still to be elucidated which fraction of the numerous spermatogonia contains the "stem cells" that support homeostatic spermatogenesis.

The morphologically most primitive spermatogonia found in the adult mouse testis are $\mathrm{A}_{\mathrm{s}}$ or $\mathrm{A}_{\text {single }}$ spermatogonia (i.e., single, isolated spermatogonia) (Fig. 2)

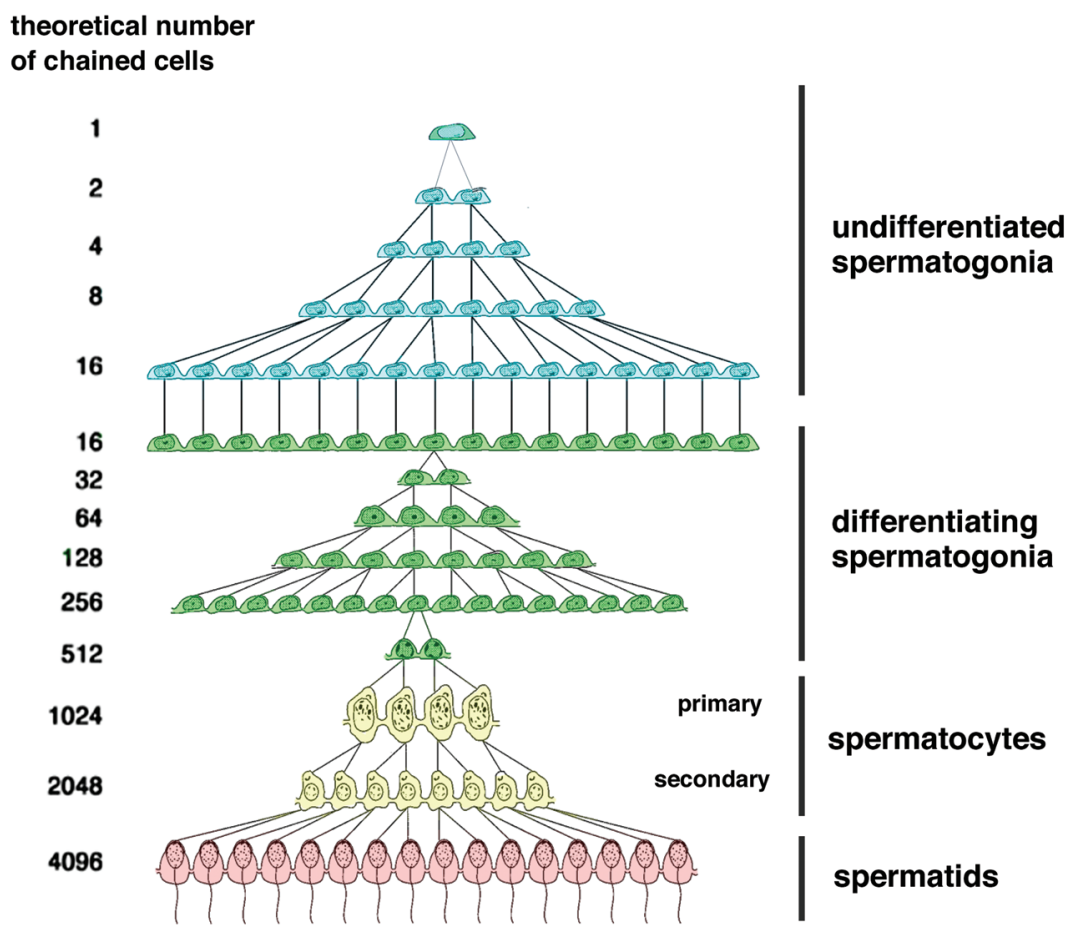

Figure 2. Spermatogenic differentiation process occurring in the mouse testis. The most primitive germ cell found in the adult mouse testis is $\mathrm{A}_{\mathrm{s}}$. As a result of subsequent incomplete cell division, syncytial cysts of $2,4,8,16 \ldots$ cells form. $\mathrm{A}_{\text {undiff }}$ (undifferentiated spermatogonia) consists of $\mathrm{A}_{\mathrm{s}}, \mathrm{A}_{\mathrm{pr}}$ (connected pairs of spermatogonia), and $\mathrm{A}_{\mathrm{al}}$ (chains of 4, 8, 16, or occasionally 32 spermatogonia). Differentiation of $\mathrm{A}_{\text {undiff }}$ into $\mathrm{A}_{1}$ differentiating spermatogonia is followed by a highly organized synchronized program leading to mature spermatozoa. See text for details. (Modified from Russell et al. 1990 [C Cache River Press].) 
(Russell et al. 1990; de Rooij and Russell 2000). Their progeny remain interconnected by intercellular bridges due to incomplete cytokinesis, forming syncytial chains of $2^{\text {n }}$ cells $(2,4,8,16$, etc.). It has been experimentally established that "undifferentiated spermatogonia" (or " $A_{\text {undiff }}$ " hereafter) - which consist of the most primitive set of spermatogonia with minimal heterochromatin condensation, including $A_{s}, A_{p r}\left(A_{\text {paired }}\right.$; interconnected pairs), and $A_{a l}$ ( $A_{\text {aligned}}$; chains of $4,8,16$, or occasionally 32 cells) - contain stem cells. $A_{\text {undiff }}$ consists of less than $1 \%$ of all testicular cells. Note that this anatomical entity is defined based on nuclear morphology and a lack of synchronicity with the surrounding differentiating spermatogonia (see next paragraph), rather than the number of syncytial cells.

In mouse seminiferous tubules, spermatogenesis proceeds as a cyclic program that takes 8.6 days, known as the seminiferous epithelial cycle (Leblond and Clermont 1952; Russell et al. 1990; de Rooij 2001). A Andiff spermatogonia persist throughout the cycle and give rise to $A_{1}$ differentiating spermatogonia once every cycle. $A_{1}$ spermatogonia subsequently go through six mitoses (each forming $\mathrm{A}_{2}, \mathrm{~A}_{3}, \mathrm{~A}_{4}$, In and $\mathrm{B}$ spermatogonia, and preleptotene primary spermatocytes) and two meiotic divisions before forming haploid spermatids, in a highly synchronous manner within a particular seminiferous tubule segment; therefore, $\mathrm{A}_{\text {undiff }}$ as a population behaves as the stem cell compartment. Compatible with this idea, $\mathrm{A}_{\text {undiff }}$ is often found as the only germ cell type that survives after insult caused by chemicals, radiation, or high temperature, which is enough for complete regeneration of spermatogenesis. However, $A_{\text {undiff }}$ is a heterogeneous population and it is unlikely that all $A_{\text {undiff }}$ act equivalently as the stem cells.

Which fraction of $A_{\text {undiff }}$ consists of the actually selfrenewing stem cell compartment in homeostasis and how does it behave (proliferate, self-renew, or die) in the testis? Decades ago, several models were proposed for this issue (Meistrich and van Beek 1993). Among them, the "A $A_{\mathrm{s}}$ model" (Huckins 1971; Oakberg 1971) is cur- rently most widely considered to be true (Meistrich and van Beek 1993; de Rooij and Russell 2000). This model proposes that $A_{s}$ is the only cell type that can act as stem cells, whereas the interconnected population of $A_{\text {undiff }}$ $\left(\mathrm{A}_{\mathrm{pr}}\right.$ and $\left.\mathrm{A}_{\mathrm{al}}\right)$ is devoid of stem cell capacity (Fig. 3, left). This comprehensive model is persuasive and attractive and is found frequently in the literature; however, it is theoretically impossible to be entirely conclusive regarding stem cell function based on "snapshots" from fixed specimens. Given that "stem cells" are defined as cells that maintain themselves while producing differentiating progeny for a long period, an experimental strategy that enables long-term analyses is warranted.

\section{POSTTRANSPLANTATION SPERMATOGENIC COLONY FORMATION}

A great breakthrough was brought about by intratubular stem cell transplantation developed by Brinster and colleagues in 1994 (Brinster and Avarbock 1994; Brinster and Zimmermann 1994; Brinster 2002). After a single cell suspension of the donor testis is transplanted into the recipient's seminiferous tubules, stem cells in the suspension reach and settle in the basal compartment (by an unknown mechanism) and proliferate to form colonies showing persisting spermatogenesis. This system has made mammalian spermatogenesis today's invaluable tissue stem cell system in which quantitative analyses by posttransplantation colony formation have been achieved, like mammalian hematopoiesis.

Taking advantage of stem cell detection by transplantation, a number of cell surface markers have been identified to enrich colony-forming stem cell activity. These and other experiments support that colony-forming activity is enriched in the $A_{\text {undiff }}$ population (Shinohara et al. 2000; Ohbo et al. 2003; Tokuda et al. 2007); however, further purification of $\mathrm{A}_{\text {undiff }}$ subfractions has not been done. This system has also led to the establishment by Shinohara and colleagues and Brinster and coworkers of

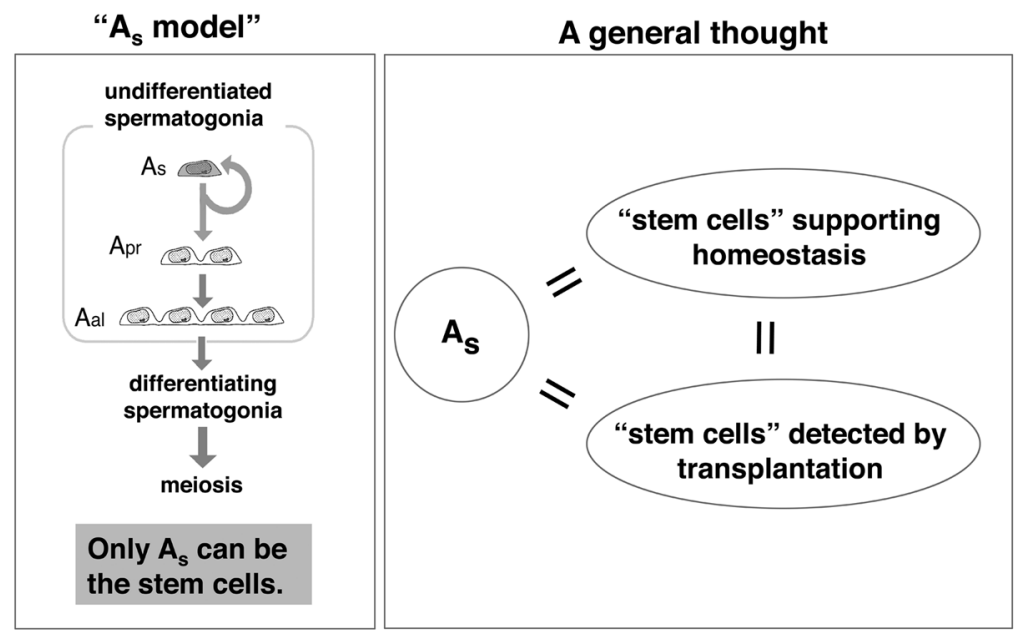

Figure 3. (Left) Schematic representation of the $\mathrm{A}_{\mathrm{s}}$ model. See text for details. (Right) General thoughts about the mouse spermatogenic stem cell system. 
long-term spermatogonial cultures that retains colonyforming stem cell activity (GS or germ-line stem cells; Kanatsu-Shinohara et al. 2003; Kubota et al. 2004). Strikingly, GS cell culture stably retains colony-forming activities for at least 2-3 years. On the other hand, only a small portion (at most several percent) of cells in these cultures exhibit colony-forming activity (KanatsuShinohara et al. 2003). Compatible with this, a significant portion of cells exhibits differentiating characteristics. Further optimization might increase the stem cell content up to, theoretically, $100 \%$, or this might reflect an unknown important property of stem cell maintenance, such as the "population effect." Again, the establishment of spermatogonial cultures that retain stem cell activity is a breakthrough that has enabled the investigation of stem cell characteristics and/or mechanisms of stem cell maintenance in vitro; this has not been achieved for hematopoietic stem cells. For example, stem cell control by the GDNF (glial-cell-line-derived neurotrophic factor) signaling pathway, which has an essential role in stem cell maintenance in vivo (Meng et al. 2000; Jijiwa et al. 2008), has been investigated extensively (Braydich-Stolle et al. 2005; Sariola and Immonen 2008).

\section{GENERAL THOUGHTS ON SPERMATOGENIC STEM CELLS}

To my understanding, the original $\mathrm{A}_{\mathrm{s}}$ model claimed that stem cell activity resides in the $\mathrm{A}_{\mathrm{s}}$ compartment but not in other morphological entities (Huckins 1971; Oakberg 1971) and did not consider whether all $\mathrm{A}_{\mathrm{s}} \mathrm{s}$ act equivalently as stem cells; however, without evidence of heterogeneity, $\mathrm{A}_{\mathrm{s}}$ has often been considered to be a synonym of stem cells, raising the idea that all $\mathrm{A}_{\mathrm{s}} \mathrm{s}$ equally act as stem cells. Indeed, in some of the literature, $A_{s}$ has been designated as $\mathrm{A}_{\text {stem. }}$. Furthermore, this idea has been easily combined with posttransplantation colony-forming stem cells. It is frequently considered to be true that all $\mathrm{A}_{\mathrm{s}}$ spermatogonia are equivalent and act as stem cells that support both homeostatic spermatogenesis and posttransplantation colony formation (Fig. 3, right).

It is acknowledged that this is a reasonable consequence in the absence of experimental links between these different means of stem cell recognition; however, it is also clear that a fuller understanding of mammalian spermatogenesis warrants experiment-based evaluation. In particular, intratubular transplantation has been designed to achieve maximum sensitivity in detecting self-renewing potential: Typically, a single cell suspension is prepared from the donor testis (an artificial breakdown of syntytia into single cells) and germ cells are depleted from the host seminiferous tubules before transplantation (this is thought to empty the stem cell niche). Therefore, it is still to be evaluated whether the "stem cells" detected by transplantation are identical to the "stem cells" that actually self-renew in homeostasis.

\section{GENETIC LABELING OF A AndFF}

The ultimate goal of our group is to fully understand the nature of the mouse spermatogenic stem cell system in the context of testicular tissue. For that purpose, we have been investigating the behavior and function of $A_{\text {undiff. }}$ Authentic identification of $\mathrm{A}_{\text {undiff }}$ was performed on whole-mount specimens (Clermont and Bustos-Obregon 1968; Huckins and Oakberg 1978) and/or based on the nuclear morphology judged from electron microscopy or high-resolution light microscopy of plastic-embedded sections (Chiarini-Garcia and Russell 2001, 2002). These strategies inevitably require fixation, making it impossible to address the live behavior of $\mathrm{A}_{\text {undiff. In addition, the }}$ reliability of identification largely depends on the skill and experience of the researchers.

On the other hand, genes that delineate this population have long been unknown. We identified that Ngn3 (neurogenin3), a bHLH (basic helix-loop-helix) transcription factor, is expressed in the $\mathrm{A}_{\text {undiff }}$ population, by means of yeast two-hybrid screening of a spermatogonia-derived cDNA library (Yoshida et al. 2004). In transgenic mice in which $\mathrm{Ngn}^{+}$cells were labeled with green fluorescent protein (GFP), isolated and interconnected spermatogonia that fulfill the authentic criteria for $\mathrm{A}_{\text {undiff }}$ were visualized (Fig. 4) (Yoshida et al. 2004). Other than Ngn3, A undiff- $^{-}$ specific expression of genes has been reported (Buaas et al. 2004; Costoya et al. 2004; Yoshida et al. 2004; Hofmann et al. 2005; Tokuda et al. 2007) that is making the heterogeneous nature of $\mathrm{A}_{\text {undiff }}$ population apparent.

Taking advantage of the genetic labeling of $\mathrm{A}_{\text {undiff }}$ by means of the Ngn3 regulatory sequence, we have established experimental systems to investigate their live behavior without disturbing normal tissue architecture.

\section{FUNCTIONAL HIERARCHY IN THE STEM CELL SYSTEM, SUGGESTED BY PULSE-LABEL EXPERIMENTS}

We first asked whether "stem cells" detected by transplantation are identical to "stem cells" that actually selfrenew in homeostasis. To address this question, it was necessary to establish an experimental strategy to identify actual self-renewing stem cells without disturbing the homeostatic testicular architecture. For that purpose, a tamoxifen-dependent Cre recombinase (CreER ${ }^{\mathrm{TM}}$; Hayashi and McMahon 2002) was expressed in $\mathrm{Ngn}^{+}$spermatogonia (Yoshida et al. 2006). In double transgenic mice with a CAG-CAT-Z reporter (Araki et al. 1995), Ngn3 ${ }^{+}$spermatogonia and their progeny were irreversibly labeled with the constitutive expression of LacZ in a tamoxifen-dependent manner.

This enabled the first quantitative detection of "actual stem cells" (i.e., a cell population that persists for a long time while producing differentiating progeny and that supports tissue homeostasis; after the definition by Potten and Loeffler [1990]). Intriguingly, contribution of the pulse-labeled subpopulation of $\mathrm{A}_{\text {undiff }}$ to "actual stem cells" and "posttransplantation colony-forming stem cells" represent a great difference ( $\sim 40$ times higher in the latter than the former (for details, see Nakagawa et al. 2007; Yoshida et al. 2007a). Therefore, these two "stem cells" represent different subpopulations of $\mathrm{A}_{\text {undiff. }}$ We concluded that in addition to actual stem cells, an extended population exits that does not self-renew but retains the potential of self-renewal, which was defined as 

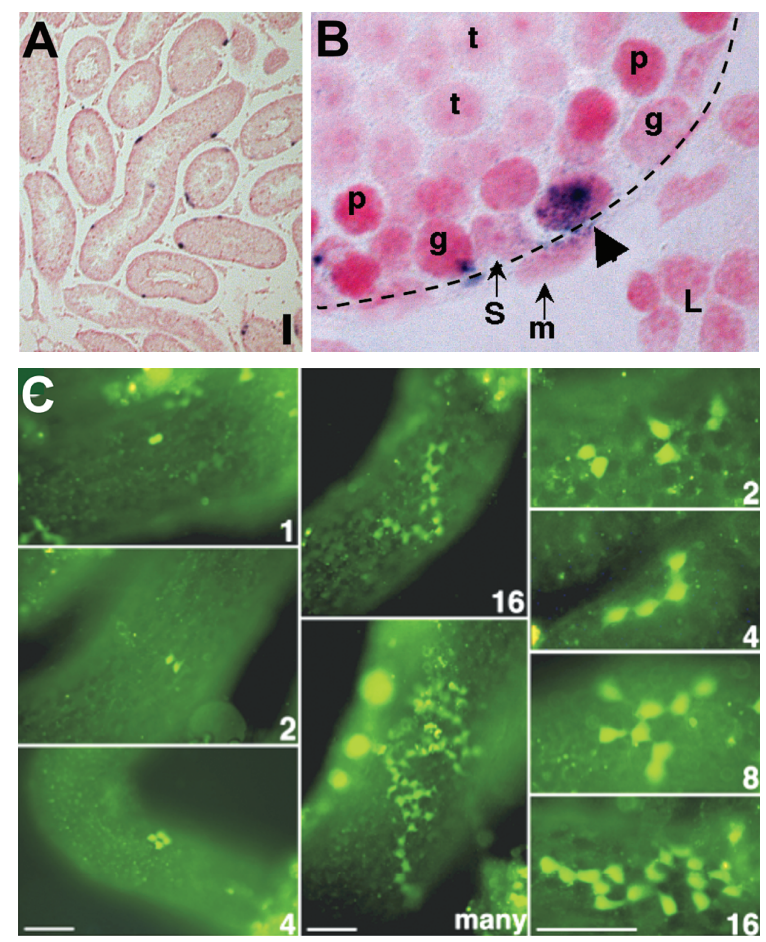

Figure 4. Ngn3-positive spermatogonia in the testis. $(A, B)$ Ngn3 expression in adult mouse testis, revealed by in situ hybridization. $\mathrm{Ngn}^{+}$cells (purple) are sparsely observed on the periphery of seminiferous tubules, counterstained with nuclear fast red $(A)$. At a higher magnification $(B)$, the signal is localized to spermatogonia with flattened nuclear morphology (arrowhead) on the basement membrane (dotted line). (g) Ngn3-negative spermatogonia; (p) pachytene spermatocytes; (t) spermatids; (S) Sertoli cells; (m) peritubular myoid cells. Bar, $100 \mu \mathrm{m}$. (C) Live visualization of $\mathrm{Ngn}^{+}$spermatogonia by GFP expression driven by the regulatory genomic sequence of the Ngn 3 gene. A small number of spermatogonia with characteristic morphology for $A_{\text {undiff }}$ (i.e., isolated cells $\left[A_{s}\right]$, or chains of $2,4,8,16$ cells $\left[A_{p r}\right.$ and $\left.A_{a 1}\right]$ ) were visualized in seminiferous tubules of the resultant transgenic mice. (Modified, with permission, from Yoshida et al. 2004 [C Elsevier].)

"potential stem cells" (see also Potten and Loeffler 1990). The "potential stem cells" were shown to rapidly turn over in homeostasis, suggesting that they consist of a transit-amplifying compartment.

Figure 5 shows a model for a hierarchical composition of the mouse spermatogenic stem cell system proposed as the simplest interpretation (Nakagawa et al. 2007). In case of actual stem cell loss, potential stem cells might revert to the self-renewing mode and replenish actual stem cells. Indeed, we also observed that actual stem cells are sometimes lost during a long period and are substituted by new actual stem cells supplied by neighboring actual stem cells (Nakagawa et al. 2007). We suppose that potential stem cells may have active roles in such normal stem cell turnover.

These results have raised a number of questions (Nakagawa et al. 2007; Yoshida et al. 2007a). Most important is the function-morphology relationship. Given that actual and colony-forming stem cells are different populations, the general thought that these two "stem cells" and $\mathrm{A}_{\mathrm{s}}$ spermatogonia are all identical (Fig. 3, right) needs to be reconsidered. Do actual and potential stem
A. Normal spermatogenesis
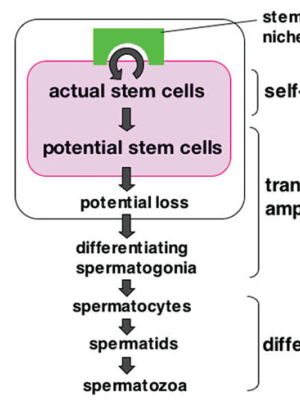

self-renewal

transit amplific ation

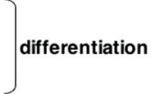

\section{stem cell}

B. Loss of actual stem cells

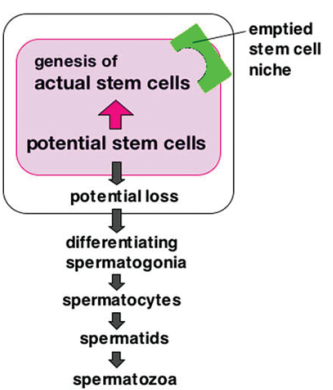

cells with self-renewing potential

undifferentiated spermatogonia

Figure 5. Proposed model of the functional compartments in mouse spermatogenesis. See text for details. (Reprinted, with permission, from Nakagawa et al. 2007 [C Elsevier].)

cells consist of different subsets of $\mathrm{A}_{\mathrm{s}}$ ? If so, $\mathrm{A}_{\mathrm{s}}$ must be heterogeneous. Are all $A_{s}$ homogeneous and do they equivalently act as actual stem cells, as the $A_{\mathrm{s}}$ model may suggest? If so, $\mathrm{A}_{\mathrm{pr}}$ or $\mathrm{A}_{\mathrm{al}}$ must include potential stem cells, which may suggest their fragmentation in homeostasis or regeneration, as observed in the Drosophila germ line (Brawley and Matunis 2004; Kai and Spradling 2004). Addressing these questions as well as challenging the actual and potential stem cell model (Fig. 5) experimentally will elucidate a fuller understanding of the stem cell system.

\section{A VASCULATURE-ASSOCIATED NICHE FOR $A_{\text {UNDIFF }}$, REVEALED BY LIVE IMAGING AND THREE-DIMENSIONAL RECONSTRUCTION}

Here, we discuss the microenvironmental niche for stem cells in the mouse testis. Most mammalian spermatogenetic stem cell research, including our work described above, does not involve localization and movement of cells. However, transplantation and/or regeneration experiments have suggested an intimate relationship between stem cells and the niche microenvironment (Shinohara et al. 2002; Hess et al. 2006). Therefore, we also aim to identify the nature and function of the mouse spermatogenic stem cell niche; however, this is difficult because seminiferous tubules do not exhibit suspicious substructures. Moreover, actual stem cells can be identified only functionally, and their histological detection has not yet been achieved. Therefore, our current aim is to clarify the niche of $\mathrm{A}_{\text {undiff. }}$

We have developed a live-imaging system during which GFP-labeled Ngn3 ${ }^{+} \mathrm{A}_{\text {undiff }}$ and their progeny (based on the residual GFP signal after down-regulation of the GFP transgene transcription) can be continuously filmed in undisturbed testes (Yoshida et al. 2007b). As a result, $\mathrm{A}_{\text {undiff }}$ showed preferential localization to the area adjacent to blood vessels and interstitial cells that surround the seminiferous tubules. This is compatible with preceding observations from mouse and rat testis sections that $\mathrm{A}_{\text {undiff }}$ shows a significant biased localization to the area facing the interstitium (Chiarini-Garcia et al. 2001, 2003 ). In addition, the dynamic migration of spermatogo- 

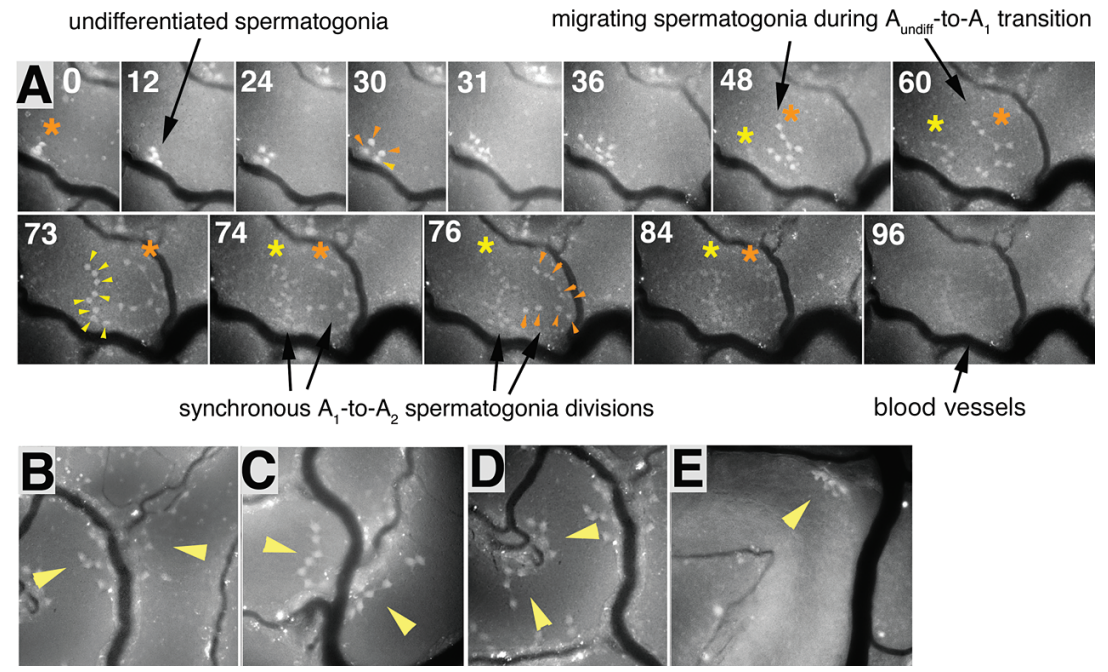

Figure 6. Localization of GFP-labeled $\mathrm{Ngn}^{+} \mathrm{A}_{\text {undiff }}$ and their relocation upon transition into differentiating spermatogonia. $(A)$ Behavior of spermatogonia upon $\mathrm{A}_{\text {undiff }}$-to- $\mathrm{A}_{1}$ transition, revealed by live imaging. Before transition ( 0 hour; the elapsed time is indicated in each panel in hours), labeled $\mathrm{A}_{\text {undiff }}$ preferentially localized to the area adjacent to the blood vessels (seen as a black line) and surrounding interstitium. Upon transition into $\mathrm{A}_{1}$, two chains of eight-cell cysts $\left(\mathrm{A}_{\mathrm{al}-8}\right.$; indexed in yellow and orange) migrated from this position to spread all over the basal compartment of the tubule ( $\sim 36-60$ hours). Subsequently, the two cysts underwent synchronous mitotic division with as short as a 2-3 hour interval, resulting in the formation of two 16-cell cysts of $\mathrm{A}_{2}$ differentiating spermatogonia (73-74 hours). Stability of the GFP protein enabled us to follow differentiating spermatogonia even after Ngn3 (enhanced GFP) transcription was shut down during the transition process. For details, see Yoshida et al. (2007b). (B-E) Examples of the vasculature-proximal localization of $\mathrm{A}_{\text {undiff. }} \mathrm{A}_{\text {undiff }}$ (arrowhead) preferentially localized to area adjacent to blood vessels, more characteristically to their branch points. In $B$ and $C, \mathrm{~A}_{\text {undiff }}$ in neighboring seminiferous tubules shows back-to-back localization over branching vessels. (Modified from Yoshida et al. 2007b [@ AAAS].)

nia from the vasculature proximity to spread throughout the tubules was also observed upon $\mathrm{A}_{\text {undiff-to- }} \mathrm{A}_{1}$ transition (Fig. 6) (Yoshida et al. 2007b). The same relocation was also supported by a three-dimensional reconstruction based on authentic morphological identification of $\mathrm{A}_{\text {undiff }}$ on serial sections (Fig. 7) (Yoshida et al. 2007b). On the basis of these observations, we proposed the area of the basal compartment of seminiferous tubules adjacent to the blood vessels as the niche for $\mathrm{A}_{\text {undiff }}$ (Fig. 8). It is also suggested that changes of the vasculature pattern may accompany niche rearrangement (Yoshida et al. 2007b).

These observations provided the idea of a "flexible" niche for the spermatogenic stem cells, which may be reversibly specified in accordance with the vasculature pattern and its reorganization. This makes a good contrast to the Drosophila germ-line stem cell niche, which is specified after a highly programmed developmental process (Kitadate et al. 2007) and, once damaged, never regenerates. However, identification of the actual stem cells in the tissue and/or live imaging of their in vivo behaviors are warranted before final identification of the "spermatogenic stem cell niche," in its real meaning of the words. Another challenge is the mechanism by which vessels and/or interstitial cells specify the niche region. Further investigations are expected to resolve these essential questions.

\section{CONCLUSIONS}

The current status of the study of mammalian (mouse) spermatogenic stem cells, including our own works, was
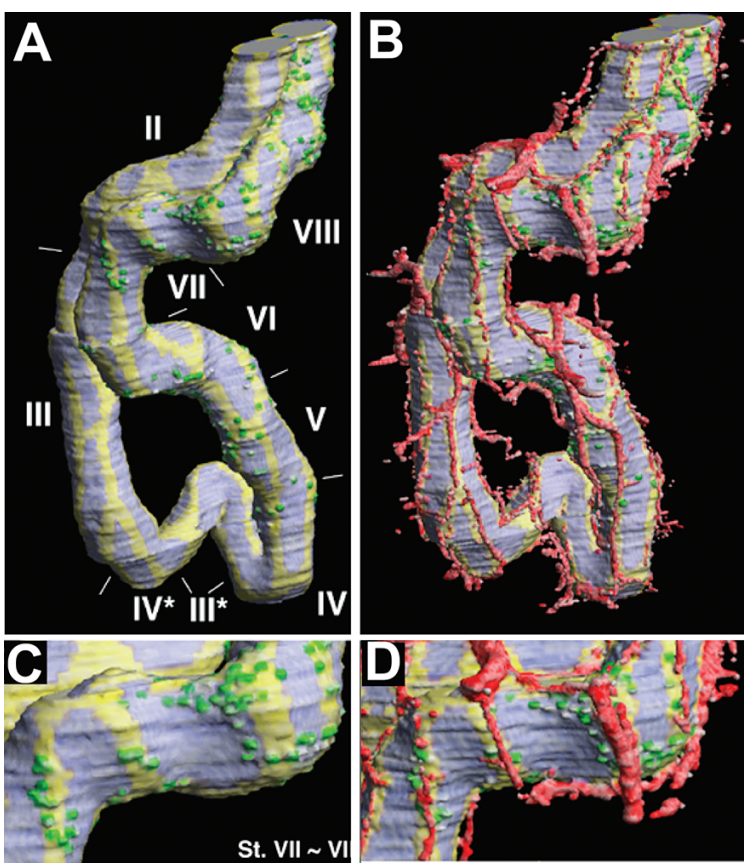

Figure 7. Localization of $\mathrm{A}_{\text {undiff }}$ by three-dimensional reconstruction. Computationally reconstituted three-dimensional image of the seminiferous tubules based on 280 serial sections. $\mathrm{A}_{\text {undiff }}$ (green) shows biased localization to the blood vessel network (red) and the area adjacent to the interstitium (yellow). $(A, C$ and $B, D)$ Images without or with blood vessels. Roman numerals indicate the stage of the seminiferous epithelium. (Reprinted from Yoshida et al. 2007b [C AAAS].) 


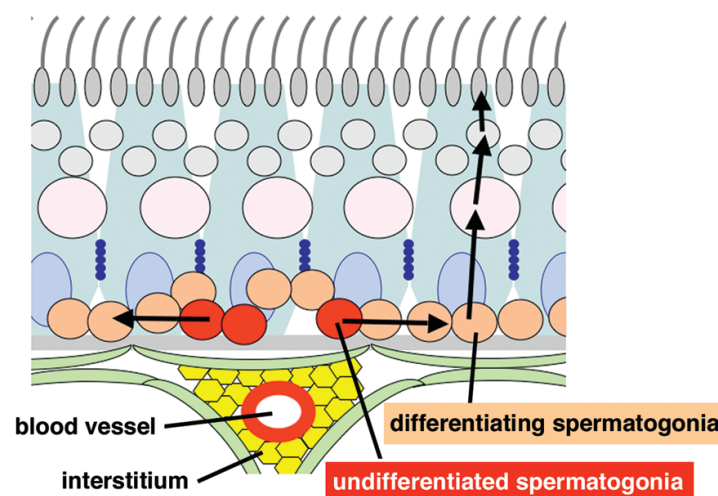

Figure 8. Schematic model of the niche microenvironment for $A_{\text {undiff. }}$ Although seminiferous tubules do not harbor specialized structures (see Fig. 1), the niche region may be specified based on the spatial relationship with the surrounding vasculature network. Within the basal compartment of the tubules, $\mathrm{A}_{\text {undiff }}$ localized the adjacent region to the blood vessels. Upon transition into $\mathrm{A}_{1}$, they migrate horizontally to spread throughout the basal compartment, followed by six mitotic divisions in the basal compartment and subsequent vertical translocation into the adluminal compartment upon entering meiosis. (Modified from Yoshida 2008 [C Kyoritsu Shuppan].)

reviewed. The mouse spermatogenic stem cell system involving a niche may be characterized by its "flexibility," which, I believe, can offer "robustness" to the entire system. This may be advantageous for mammals, which have a far larger body (i.e., organs harbor many more cells) and live much longer (i.e., the stem cell system needs to persist much longer). Further investigations will reveal more about the "flexible" mouse spermatogenic stem cell system.

\section{ACKNOWLEDGMENTS}

The work of our group introduced in this manuscript was performed in the Department of Pathology and Tumor Biology, Graduate School of Medicine, Kyoto University. I am deeply grateful to the tolerant and continuous support of Professor Yo-ichi Nabeshima. I also thank my colleagues, especially Dr. Toshinori Nakagawa, for his involvement in the pulse-label experiments, and Ms. Mamiko Sukeno and Mr. Tsutomu Obata for their excellent technical assistance. These studies were financially supported by grants-in-aid for Scientific Research from MEXT (Ministry of Education, Culture, Sports, Science and Technology) and JSPS (Japan Society for the Promotion of Science), the PRESTO (Precursory Research for Embryonic Science and Technology) program of the JST (Japan Science and Technology Agency), The Naito Foundation, and The Uehara Memorial Foundation.

\section{REFERENCES}

Araki, K., Araki, M., Miyazaki, J., and Vassalli, P. 1995. Sitespecific recombination of a transgene in fertilized eggs by transient expression of Cre recombinase. Proc. Natl. Acad. Sci. 92: 160-164.

Brawley, C. and Matunis, E. 2004. Regeneration of male germ- line stem cells by spermatogonial dedifferentiation in vivo. Science 304: 1331-1334.

Braydich-Stolle, L., Nolan, C., Dym, M., and Hofmann, M.C. 2005. Role of glial cell line-derived neurotrophic factor in germ-line stem cell fate. Ann. N.Y. Acad. Sci. 1061: 94-99.

Brinster, R.L. 2002. Germline stem cell transplantation and transgenesis. Science 296: 2174-2176.

Brinster, R.L. and Avarbock, M.R. 1994. Germline transmission of donor haplotype following spermatogonial transplantation. Proc. Natl. Acad. Sci. 91: 11303-11307.

Brinster, R.L. and Zimmermann, J.W. 1994. Spermatogenesis following male germ-cell transplantation. Proc. Natl. Acad. Sci. 91: 11298-11302.

Buaas, F.W., Kirsh, A.L., Sharma, M., McLean, D.J., Morris, J.L., Griswold, M.D., de Rooij, D.G., and Braun, R.E. 2004. Plzf is required in adult male germ cells for stem cell selfrenewal. Nat. Genet. 36: 647-652.

Chiarini-Garcia, H. and Russell, L.D. 2001. High-resolution light microscopic characterization of mouse spermatogonia. Biol. Reprod. 65: 1170-1178.

Chiarini-Garcia, H. and Russell, L.D. 2002. Characterization of mouse spermatogonia by transmission electron microscopy. Reproduction 123: 567-577.

Chiarini-Garcia, H., Raymer, A.M., and Russell, L.D. 2003. Non-random distribution of spermatogonia in rats: Evidence of niches in the seminiferous tubules. Reproduction 126: 669-680.

Chiarini-Garcia, H., Hornick, J.R., Griswold, M.D., and Russell, L.D. 2001. Distribution of type A spermatogonia in the mouse is not random. Biol. Reprod. 65: 1179-1185.

Clermont, Y. and Bustos-Obregon, E. 1968. Re-examination of spermatogonial renewal in the rat by means of seminiferous tubules mounted "in toto." Am. J. Anat. 122: 237-247.

Costoya, J.A., Hobbs, R.M., Barna, M., Cattoretti, G., Manova, K., Sukhwani, M., Orwig, K.E., Wolgemuth, D.J., and Pandolfi, P.P. 2004. Essential role of Plzf in maintenance of spermatogonial stem cells. Nat. Genet. 36: 653-659.

Decotto, E. and Spradling, A.C. 2005. The Drosophila ovarian and testis stem cell niches: Similar somatic stem cells and signals. Dev. Cell 9: 501-510.

de Rooij, D.G. 2001. Proliferation and differentiation of spermatogonial stem cells. Reproduction 121: 347-354.

de Rooij, D.G. and Russell, L.D. 2000. All you wanted to know about spermatogonia but were afraid to ask. J. Androl. 21: 776-798.

Hayashi, S. and McMahon, A.P. 2002. Efficient recombination in diverse tissues by a tamoxifen-inducible form of Cre: A tool for temporally regulated gene activation/inactivation in the mouse. Dev. Biol. 244: 305-318.

Hess, R.A., Cooke, P.S., Hofmann, M.C., and Murphy, K.M. 2006. Mechanistic insights into the regulation of the spermatogonial stem cell niche. Cell Cycle 5: 1164-1170.

Hofmann, M.C., Braydich-Stolle, L., and Dym, M. 2005. Isolation of male germ-line stem cells; influence of GDNF. Dev. Biol. 279: 114-124.

Huckins, C. 1971. The spermatogonial stem cell population in adult rats. I. Their morphology, proliferation and maturation. Anat. Rec. 169: 533-557.

Huckins, C. and Oakberg, E.F. 1978. Morphological and quantitative analysis of spermatogonia in mouse testes using whole mounted seminiferous tubules. I. The normal testes. Anat. Rec. 192: 519-528.

Jijiwa, M., Kawai, K., Fukihara, J., Nakamura, A., Hasegawa, M., Suzuki, C., Sato, T., Enomoto, A., Asai, N., Murakumo, Y., and Takahashi, M. 2008. GDNF-mediated signaling via RET tyrosine 1062 is essential for maintenance of spermatogonial stem cells. Genes Cells 13: 365-374.

Kai, T. and Spradling, A. 2004. Differentiating germ cells can revert into functional stem cells in Drosophila melanogaster ovaries. Nature 428: 564-569.

Kanatsu-Shinohara, M., Ogonuki, N., Inoue, K., Miki, H., Ogura, A., Toyokuni, S., and Shinohara, T. 2003. Long-term proliferation in culture and germline transmission of mouse male germline stem cells. Biol. Reprod. 69: 612-616. 
Kitadate, Y., Shigenobu, S., Arita, K., and Kobayashi, S. 2007. Boss/Sev signaling from germline to soma restricts germlinestem-cell-niche formation in the anterior region of Drosophila male gonads. Dev. Cell. 13: 151-159.

Kubota, H., Avarbock, M.R., and Brinster, R.L. 2004. Growth factors essential for self-renewal and expansion of mouse spermatogonial stem cells. Proc. Natl. Acad. Sci. 101: 1648916494.

Leblond, C.P. and Clermont, Y. 1952. Definition of the stages of the cycle of the seminiferous epithelium in the rat. Ann. N.Y. Acad. Sci. 55: 548-573.

Meistrich, M.L. and van Beek, M.E. 1993. Spermatogonial stem cells. In Cell and molecular biology of the testis (ed. C. Desjardins and L.L. Ewing), pp. 266-295. Oxford University Press, New York

Meng, X., Lindahl, M., Hyvönen, M.E., Parvinen, M., de Rooij, D.G., Hess, M.W., Raatikainen-Ahokas, A., Sainio, K., Rauvala, H., Lakso, M., et al. 2000. Regulation of cell fate decision of undifferentiated spermatogonia by GDNF. Science 287: 1489-1493.

Nakagawa, T., Nabeshima, Y., and Yoshida, S. 2007. Functional identification of the actual and potential stem cell compartments in mouse spermatogenesis. Dev. Cell 12: 195-206.

Oakberg, E.F. 1971. Spermatogonial stem-cell renewal in the mouse. Anat. Rec. 169: 515-531.

Ohbo, K., Yoshida, S., Ohmura, M., Ohneda, O., Ogawa, T., Tsuchiya, H., Kuwana, T., Kehler, J., Abe, K., Schöler, H.R., and Suda, T. 2003. Identification and characterization of stem cells in prepubertal spermatogenesis in mice. Dev. Biol. 258: 209-225.

Potten, C.S. and Loeffler, M. 1990. Stem cells: Attributes, cycles, spirals, pitfalls and uncertainties. Lessons for and from the crypt. Development 110: 1001-1020.
Russell, L., Ettlin, R., Sinha Hikim, A., and Clegg, E. 1990 Histological and histopathological evaluation of the testis. Cache River Press, Clearwater, Florida.

Sariola, H. and Immonen, T. 2008. GDNF maintains mouse spermatogonial stem cells in vivo and in vitro. Methods Mol. Biol. 450: 127-135.

Shinohara, T., Orwig, K.E., Avarbock, M.R., and Brinster, R.L. 2000. Spermatogonial stem cell enrichment by multiparameter selection of mouse testis cells. Proc. Natl. Acad. Sci. 97: $8346-8351$.

Shinohara, T., Orwig, K.E., Avarbock, M.R., and Brinster, R.L. 2002. Germ line stem cell competition in postnatal mouse testes. Biol. Reprod. 66: 1491-1497.

Tokuda, M., Kadokawa, Y., Kurahashi, H., and Marunouchi, T. 2007. CDH1 is a specific marker for undifferentiated spermatogonia in mouse testes. Biol. Reprod. 76: 130-141.

Yoshida, S. 2008. "Flexible" stem cell-niche system in mouse spermatogenesis (transl.). Tanpakushitsu Kakusan Koso (Protein, Nucleic Acid and Enzyme) 53: 1125-1132.

Yoshida, S., Nabeshima, Y., and Nakagawa, T. 2007a. Stem cell heterogeneity: Actual and potential stem cell compartments in mouse spermatogenesis. Ann. N.Y. Acad. Sci. 1120: 47-58.

Yoshida, S., Sukeno, M., and Nabeshima, Y. 2007b. A vasculature-associated niche for undifferentiated spermatogonia in the mouse testis. Science 317: 1722-1726.

Yoshida, S., Sukeno, M., Nakagawa, T., Ohbo, K., Nagamatsu, G., Suda, T., and Nabeshima, Y. 2006. The first round of mouse spermatogenesis is a distinctive program that lacks the selfrenewing spermatogonia stage. Development 133: 1495-1505.

Yoshida, S., Takakura, A., Ohbo, K., Abe, K., Wakabayashi, J., Yamamoto, M., Suda, T., and Nabeshima, Y. 2004. Neurogenin3 delineates the earliest stages of spermatogenesis in the mouse testis. Dev. Biol. 269: 447-458. 


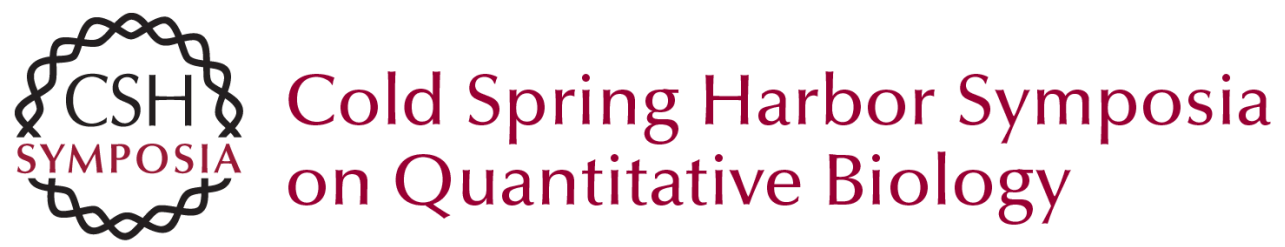

\section{Spermatogenic Stem Cell System in the Mouse Testis}

S. Yoshida

Cold Spring Harb Symp Quant Biol 2008 73: 25-32 originally published online January 15, 2009 Access the most recent version at doi:10.1101/sqb.2008.73.046

References This article cites 41 articles, 14 of which can be accessed free at: http://symposium.cshlp.org/content/73/25.full.html\#ref-list-1

License

Email Alerting Receive free email alerts when new articles cite this article - sign up in the box at the Service top right corner of the article or click here.

To subscribe to Cold Spring Harbor Symposia on Quantitative Biology go to:

http://symposium.cshlp.org/subscriptions 